\title{
JUVENILE PRODUCTION OF THE FRESHWATER PRAWN CRYPHIOPS CAEMENTARIUS (DECAPODA: PALAEMONIDAE) UNDER LABORATORY CONDITIONS IN COQUIMBO, CHILE
}

\section{PRODUCCION DE JUVENILES EN CONDICIONES DE LABORATORIO DEL CAMARON DE RIO CRYPHIOPS CAEMENTARIUS (DECAPODA: ALAEMONIDAE) EN COQUIMBO, CHILE}

\author{
Jaime Meruane ${ }^{1 *}$, Miguel Rivera, Cristina Morales, César Galleguillos \\ \& Hidetsuyo Hosokawa ${ }^{2}$ \\ ${ }^{1}$ Departamento de Acuicultura, Facultad de Ciencias del Mar, Universidad Católica del Norte, \\ Casilla 117, Coquimbo-Chile. \\ ${ }^{2}$ Laboratory of Fish Nutrition, Faculty of Agriculture, Kochi University, Monobe, Nankoku 783-8502, Japan, \\ *Corresponding author. Email: jmeruane@ucn.cl
}

\begin{abstract}
Two culture experiments from 1995 until 1997 were carried out with larvae obtained from gravid females of Cryphiops caementarius (Molina 1782), to define a methodology in order to produce juvenile using controlled conditions of water temperature, salinity and feeding. Time in culture of larval development and the survival rate were determined. Two distinct types of culture systems were studied. Both systems incorporated a standard alimentation using nauplius of Artemia sp. plus microalgae; however the second system included, in addition, a supplement of fish and chiken eggs. The decrease in survival rate in both cultures systems was related to morphological changes in each stage of development. Juveniles were obtained after 98 days of culture with the first culture system, whereas in the second culture system, the time to reach the first juvenile stage was 62 days. In addition, an increase in the values for metamorphosis synchronism induced a good amount of metamorphosed animals (juveniles) during the time involved in this study.
\end{abstract}

KEYwords: Chile, freshwater prawn, larvae, culture technology, metamorphosis, juvenile.

\section{RESUMEN}

Con larvas obtenidas de hembras grávidas de Cryphiops caementarius (Molina 1782), se realizó dos experiencias de cultivo entre 1995 y 1997. Estas experiencias fueron diseñadas con el propósito de definir una metodología que permitiera producir juveniles de la especie, utilizando condiciones controladas de temperatura, salinidad y alimentación. Durante este estudio se determinó el desarrollo larval, su duración y la tasa de supervivencia. La disminución en la tasa de supervivencia en ambos cultivos fue coincidente con los cambios morfológicos en cada estado de desarrollo. Durante el primer cultivo, el estado de primer juvenil fue alcanzado a los 98 días. Durante la segunda experiencia, el tiempo empleado en la obtención del primer estado de juvenil fue de 62 días. Durante ésta, se utilizó un suplemento alimenticio consistente en pescado y huevos de gallina. Otro de los resultados importantes logrados fue el aumento en los valores de sincronía en la metamorfosis, lo cual permitió obtener una importante cantidad de animales metamorfoseados (juveniles) durante el tiempo involucrado en el estudio.

Palabras claves: Chile, camarón de río, larvas, tecnología de cultivo, metamorfosis, juveniles. 
Juvenile production of a freshwater prawn in Chile. Meruane, J. ET AL.

\section{INTRODUCTION}

Cryphiops caementarius (Molina 1782) (Decapoda: Palaemonidae), is a freshwater prawn distributed from the South of Perú $\left(10^{\circ} \mathrm{S}\right)$ to Northern central Chile $\left(30^{\circ}\right.$ S) (Bahamonde \& Vila 1971, Castro 1966, Elias 1960, Viacava et al. 1978). Ripe and gravid females move downstream seeking estuarine conditions to spawn. After hatching larvae stay in the estuarine zone and/or the sea, returning to the river as juveniles (Norambuena 1977, Rivera \& Meruane 1987). This conduct has been reported for several species of the genus Macrobrachium with prolongated developmental pattern (New \& Singholka 1984, Jalihal et al. 1993, New 1995, 2005). In Chile, the commercial production of freshwater prawn is not very developed, yet. The culture companies get the juveniles directly from rivers, instead of producing them in a hatchery. In order to incorporate this activity as an industry, it is necessary to count with abundant and constant juvenile production. It is necessary ensure culture success in spite of the availability of "seeds" from nature.

Artificial productions of postlarvae or juvenile in hatcheries have been attempted by several authors using different techniques. However, the main problems found were the variability in the number of larval stages, length of developmental period, food, environmental requirements and morphological changes of larvae during their life cycle. Sanzana (1976) described the first three stages of development. Munaylla (1977) obtained $C$. caementarius postlarvae with 17 zoeal stages. Viacava et al. (1978) studied the larval survival, with salinity variation and with and without feeding, only during the first and second stages of development. Hernández (1981) reached the $4^{\circ}$ stage of mysis but without a description of larval stages. Schmiede et al (1982) carried out larval development at experimental conditions during 130 days and with 16 moult cycles. Rivera et al. (1983) maintained larvae during 153 day reaching the $10^{\circ}$ zoeal stage. Rivera \& Meruane (1987) studied the effects of salinity and food on larval survival and metamorphosis of $C$. caementarius and found that the first juvenile stage was reached with a reduction of $10 \%$ at 80 days of culture.

The purpose of this study was to develop the technology culture for larvae of Cryphiops caementarius under controlled conditions through adjusting and modifying existing techniques to obtain the complete cycle until the first juvenile stage.

\section{MATERIALS AND METHODS}

An experimental hatchery for the production of juveniles of Cryphiops caementarius was set up at the facilities of the Universidad Católica del Norte, Coquimbo $\left(29^{\circ} 58^{\prime} \mathrm{S} ; 71^{\circ} 21^{\prime} \mathrm{W}\right)$, Chile. It included one water treatment room, which had a series of cartridge filters $(25,10,5$ and $1 \mu \mathrm{m})$, a water heater exchanger and UV equipment (QR-80) for sterilization. During ontogeny, Cryphiops caementarius needs different salinity concentrations. Seawater was obtained from La Herradura Bay $\left(29^{\circ} 58^{\prime} \mathrm{S} ; 71^{\circ} 21^{\prime} \mathrm{W}\right)$ using of two lift pumps (ESPAFlipper 1,5" Model 75), while freshwater was obtained from the domestic supply. These water sources were used to prepare water at desired salinities (Table I). The air was carried from the blower room and added permanently to the tanks through a 3/4" (1,9 $\mathrm{cm}) \mathrm{PVC}$ hose. Another room was available to prepare the feed for larvae (microalgae and Artemia nauplii). The larviculture room had 2 tanks of 1000 L of capacity, operating alternatively so that one remained as a reservoir tank to be used the next day. Water and feeding conditions during the larval culture are shown in Table I.

Females with fertilized eggs were obtained from a prawn farm and also from the natural environment, and transported to the experimental laboratory. Here they were placed individually in $100 \mathrm{~L}$ tanks with freshwater and continuous aeration. The spawning occured during the first night, and early in the morning larvae were removed, examined and transported to the larviculture room.

Two cultures at different times were developed. The first started with a density of 23 larvae $\mathrm{L}^{-1}$, and added feed was Artemia at 1 nauplii $\mathrm{mL}^{-1}$, microalgae at $50,000-150,000 \mathrm{cel} \mathrm{mL}^{-1}$, to $25^{\circ} \mathrm{C}$ water temperature, salinity at $20 \%$ and $100 \%$ daily of water exchange. The second culture started at the same salinity, temperature and food conditions, but at a density of 40 larvae $\mathrm{L}^{-1}$. In addition, this second culture received triturated fresh fish flesh and boiled chicken eggs as nutritional supplements. In both cultures, the salinity values were decreased gradually in relation to the developmental stage of larvae with the purpose to get juveniles (Table I). 
$\stackrel{\sim}{0}$ TABLE I. Culture conditions for production of Cryphiops caementarius juvenile.

TABLA I. Condiciones de cultivo para la producción de juveniles de Cryphiops caementarius.

\begin{tabular}{|c|c|c|c|c|c|c|}
\hline \multirow[b]{2}{*}{ Stages } & \multicolumn{2}{|c|}{ Water conditions } & \multirow[b]{2}{*}{ Salinity $(\% \circ)$} & \multirow[b]{2}{*}{ Microalgae (cell m²) } & \multicolumn{2}{|l|}{ Feeding conditions } \\
\hline & Daily exchange (\%) & Temperature $\left({ }^{\circ} \mathrm{C}\right)$ & & & Artemia (nauplii $\mathrm{mL}^{-1}$ ) & Artificial food $\left(\mathrm{g} \mathrm{L}^{-1}\right)$ \\
\hline Zoea 1 & 100 & 25 & 10 & 80,000 & 1,5 &.-- \\
\hline Zoea 2 & 100 & 25 & 15 & 80,000 & 1,5 & $0.01-0,02$ \\
\hline Zoea 3 & 100 & 25 & 20 & 80,000 & 1.5 & $0.01-0,02$ \\
\hline Zoea 4 & 100 & 25 & 25 & 100,000 & 1,5 & $0.03-0,05$ \\
\hline Zoea 5 & 100 & 25 & 25 & 150,000 & 2,0 & $0,03-0,05$ \\
\hline Zoea 6 & 100 & 25 & 30 & 150,000 & 2,0 & $0,03-0,05$ \\
\hline Zoea 7 & 100 & 25 & 30 & 150,000 & 2,0 & $0,05-0,07$ \\
\hline Zoea 8 & 100 & 25 & 30 & 150,000 & 2,0 & $0,05-0,07$ \\
\hline Zoea 9 & 100 & 25 & 30 & 150,000 & 2,0 & $0,05-0,07$ \\
\hline Zoea 10 & 100 & 25 & 30 & 150,000 & 2,0 & $0,05-0,07$ \\
\hline Zoea 11 & 100 & 25 & 30 & 100,000 & 3,0 & $0,09-0,12$ \\
\hline Zoea 12 & 100 & 25 & 30 & 100,000 & 3,0 & $0,09-0,12$ \\
\hline Zoea 13 & 100 & 25 & 30 & 100,000 & 3,0 & $0,09-0,12$ \\
\hline Zoea 14 & 100 & 25 & 30 & 100,000 & 3,0 & $0,09-0,12$ \\
\hline Zoea 15 & 100 & 25 & 30 & 100,000 & 3,0 & $0,09-0,12$ \\
\hline Zoea 16 & 100 & 25 & 25 & 80,000 & 3,0 & $0,14-0,16$ \\
\hline Zoea 17 & 100 & 25 & 20 & 80,000 & 3,0 & $0,14-0,16$ \\
\hline Zoea 18 & 100 & 25 & 15 & 50,000 & 3,0 & $0,14-0,16$ \\
\hline Juvenile & 100 & 25 & 5 &.-- &.-- & $0,20-0,22$ \\
\hline
\end{tabular}


Tanks were controlled every day and accumulated survival was registered during all culture cycle. The larval stages were determined and quantified according to previous descriptions made by Rivera et al. 1987. Larval stage endpoints were when 50\% of larvae developed into the next stage (Table II).

TABLE II. Duration of each larval stage.

TABLa II. Duración de cada estado de desarrollo larval.

\begin{tabular}{lcc}
\hline & & \multicolumn{2}{c}{ Duration in days } \\
\cline { 3 - 3 } Stages & First culture & Second culture \\
\hline Zoea 1 & 3 & 3 \\
Zoea 2 & 13 & 2 \\
Zoea 3 & 6 & 3 \\
Zoea 4 & 6 & 4 \\
Zoea 5 & 5 & 3 \\
Zoea 6 & 4 & 4 \\
Zoea 7 & 6 & 4 \\
Zoea 8 & 6 & 6 \\
Zoea 9 & 4 & 4 \\
Zoea 10 & 5 & 2 \\
Zoea 11 & 6 & 3 \\
Zoea 12 & 5 & 5 \\
Zoea 13 & 5 & 4 \\
Zoea 14 & 5 & 3 \\
Zoea 15 & 6 & 3 \\
Zoea 16 & 5 & 3 \\
Zoea 17 & 5 & 3 \\
Zoea 18 & 3 & 3 \\
First juvenile & Day 98 & Day 62 \\
\hline
\end{tabular}

RESULTS

\section{FIRST CULTURE}

The daily survival rate of Cryphiops caementarius larvae showed that the main decrease was coincident with each of the changes in the developmental stages. A high mortality was observed between zoea 2 to zoea 5, probably due to changes made in the feeding system. At this point the quality, quantity and the frequency of food supply should be adjusted to avoid a lengthening of zoea 2 stage. The prolongation of this stage demonstrated an increase in mortality during 10 to 20 days of culture. This is associated with the natural mortality due to developmental changes of these individuals. The average moulting time for zoea 2 is 4 to 5 days. In the culture process mortality diminishes once each of the factors involved in the development and growth of larvae are regulated; such as quality and quantity of food, culture water quality and stable water temperature. As seen in Fig. 1 the daily larval mortality during 100 days of culture displayed an accumulated value close to $50 \%$, and the first postlarvae or juvenile was obtained at 98 days. The highest mortalities were observed during 10 to 30 days of culture. At this time larvae were very sensitive to handling (water replacement) and to the adjustment of external factors as food, temperature and salinity. This indicated that the mortality increases with lengthening of time in zoea 2 stage is observed. As the larvae continued its development and growth, the culture conditions became less significant for larval survival. However, an increase in nutritional requirements and consequently an increment in metabolic waste products during the progression of larval development necessitate that the control of water quality be the first priority. The increase in mortality during days 45 and 50 could be results from the metamorphosis induction through changes in culture water salinity (Fig. 1). 

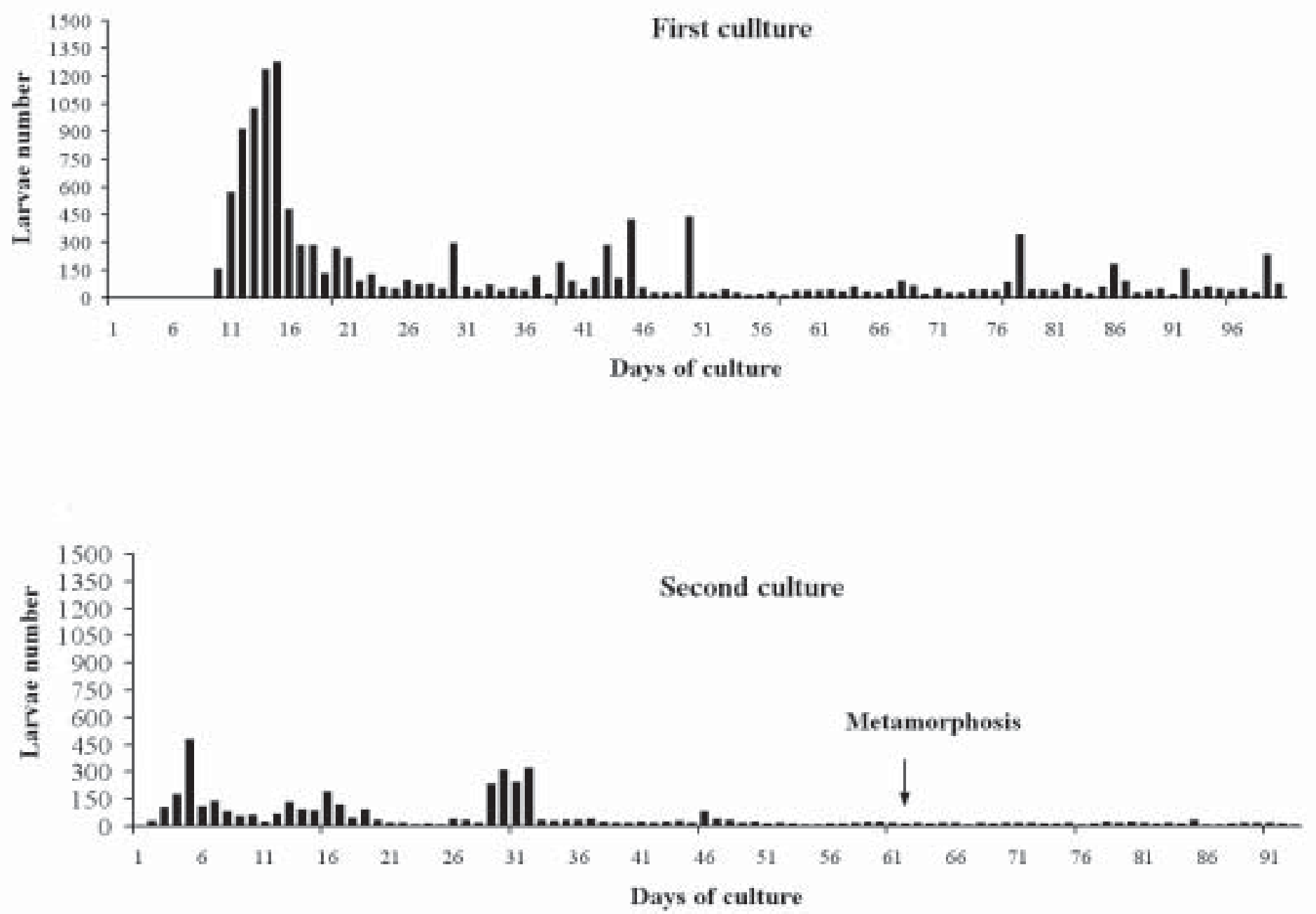

FIGURE 1 . Daily mortality of C. caementarius larvae during both cultures.

Figura 1. Mortalidad diaria de larvas de Cryphiops caementarius en ambos cultivos. 


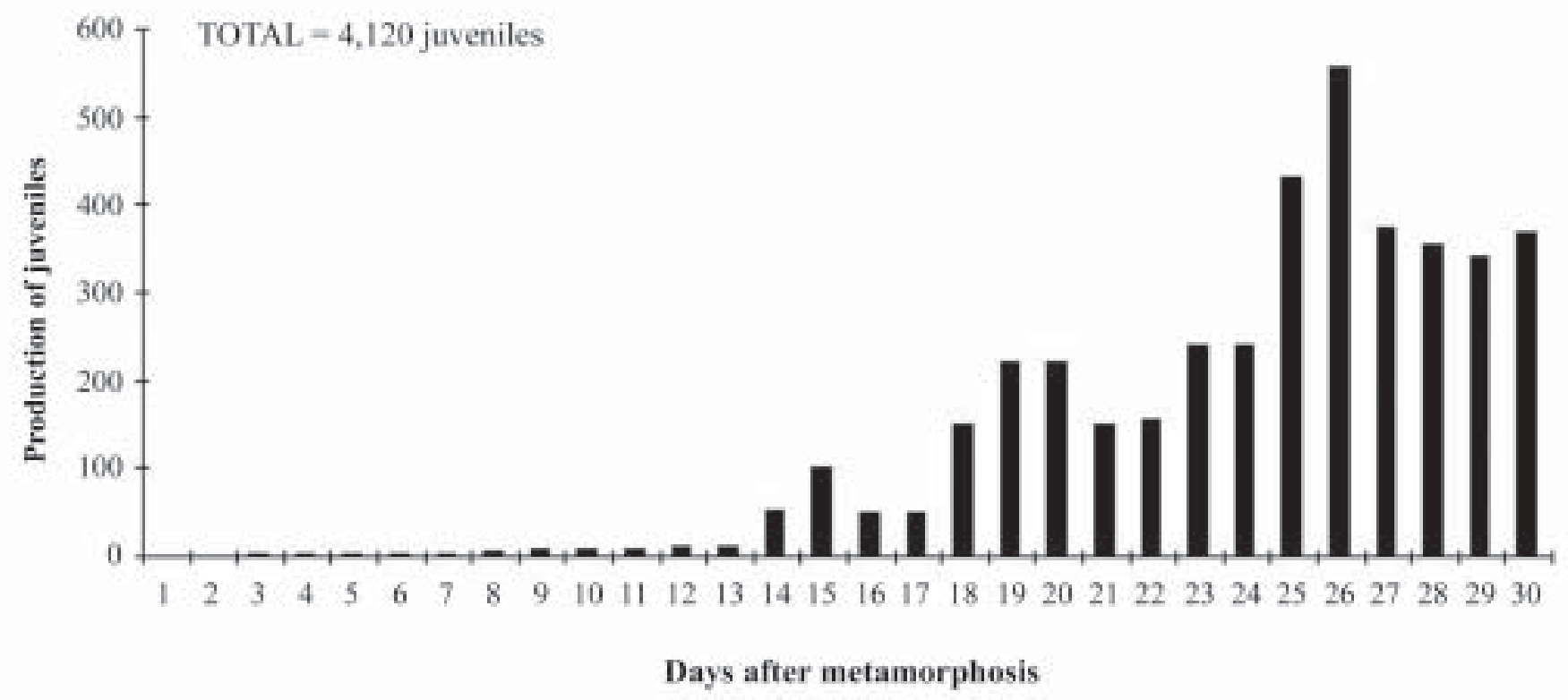

FIGURE 2. Total production of $C$. caementarius juvenile during the second culture.

Figura 2. Producción total de juveniles de Cryphiops caementarius durante el segundo cultivo. 
The duration of the zoea 2 stage was 13 days (Table II), situation that increased the mortality. The next stages of development were inside of the normal ranges of time, according to previous investigations carried out by Rivera et al. (1987).

All these information indicated that the most critical moments of the larval development of these prawns are directly related to morphological changes associated to a new developmental stage.

Adjustment of the quantities and frequencies of feeding, the standardization of the values of water temperature, and the maintenance of culture water conditions are the factors that need to be evaluated during the second larval mass culture in order to establish if is possible a synchronism in larval stage changes, which apparently would lead to an increment of the survival rate and probably a decrease of the larval cycle time.

\section{SeCOND CUlture}

During this culture, an important mortality between the stages of zoea 2 and zoea 5 also occurred, although considerably minor that in the first culture conditions. This second culture was properly controlled incrementing the quantity of food (fish and egg) delivered ad libitum. This was carried out by a redistribution in the frequency of Artemia feeding (one in the morning, another in the afternoon and one during the night), and maintaining the microalgae concentration constant. New microalgae at densities of $50,000 \mathrm{cell} / \mathrm{mL}^{-1}$ were added after each total replacement of water (Table I).

The feeding regime probably diminished the permanency of larvae in each stage, especially during the zoea 2, exhibited notably decrease in larvae mortalities (Fig. 1).

Around day 30 of culture a mass infection with filamentous bacteria from the natural source of seawater was detected and caused an abrupt increment in the mortality rate (Fig. 1) in all the culture tanks. Once the microorganisms were identified, an antibiogram was carried out and the bacteria were found to be sensitive to Tetracycline $\AA$ at a concentration of $3 \mathrm{mg} / \mathrm{L}^{-1}$. Larvae were incubated with Tetracycline ${ }^{\circledR}$ for one minute and inmediately after the treatment, the larvae were seeded in previous disinfected tanks with microfiltered and sterilized water, producing a massive moulting of the animals during the day, which eliminated great part to the bacteria. A preventive treatment with Tetracycline ${ }^{\circledR}$ was done every one month approximately, and until the larvae reached the stage of zoea 10. After that massive contamination with bacteria the system did not undergo any other alteration.

The first juvenile was obtained after 62 days of culture and 36 days earlier than in the first culture (Fig.1). The juvenile production increased progressively, and after 19 days they were between 200 and 300 new juveniles daily, and from the $22^{\text {nd }}$ day after metamorphosis, over 4,000 individuals were obtained (Fig. 2).

\section{DISCUSSION}

The harvested larvae in both cultures showed a normal behavior with respect to similar experiments done by Rivera \& Meruane (1987) and available information on cultivation of larvae of M. rosenbergii done in others countries, especially from Southeast Asia (New \& Singholka 1984, New 1995; 2005).

C. caementarius and M. rosenbergii belong to the Family Palaemonidae. In general, they have similar requirement during their development and growth. However required temperature and salinity differ. $M$. rosenbergii completes larval development at temperatures between 27 to $30^{\circ} \mathrm{C}$ (New \& Singholka 1984), while C. caementarius does so at 18 to $20^{\circ} \mathrm{C}$ (Bahamonde \& Vila 1971, Báez et al. 1983, Elias 1960, Nava 1980, Rivera et al. 1983, Rivera \& Meruane 1987). They also require different salinities (New \& Singholka 1984, Rivera $\&$ Meruane 1987). These species have larval stages that naturally occur in estuaries or the sea, while for metamorphosis freshwater is required. If these conditions are not regulated, the larvae experiment frequent moults that do not always led to a change of developmental stage, but delaying the metamorphosis. Postponement of metamorphosis causes high growth variability, mortality and vulnerability to diseases.

The first culture allowed to develop a methodology to obtain a good quantity of larvae (> 50\% of viability) coming from ovigerous females gathered at the natural environment or from the culture ponds. During this research it was also possible to obtain adequate larval survivals until the premetamorphic 
stage (> 50\%), even considering the delay of intermoult period due to an insufficient feeding of larvae, detection and treatment of potentials illness, search of inducer that permits the metamorphosis and one correct management for adaptation of juveniles to mass culture tanks conditions. The first culture culminated with $\approx 400$ juveniles produced after 98 days under laboratory conditions and valuable information to be applied during the second cultivation was gotten.

The improvement in key factors detected during the first culture and applied during the second experiment resulted in the attainment of juveniles 36 days before the first experiment. Interestingly the metamorphosis synchronism was incremented, permitting a sustained production of juveniles $(4,120)$ during the time involved in this study. For this reason is necessary to improve even more the synchronism rate thereby achieving better percentages of metamorphosis in each one of the cultivations to be carried out. Other factors which need more investigation are the determination of the composition, ration and frequency of diets, the identification of new alternatives to the natural diets used until now, the water culture conditions (biological and chemical), as well as the identification of inducers and their effects on the metamorphosis and their synchronism.

Our results shows, the importance of factors such salinity, temperature and feeding conditions on larval production and subsequent juvenile yield. The achieved methodology assures the production of animals and could provide prime material (juvenile) produced at controlled conditions to farmers producing culture and to those that do so in the near future.

\section{ACKNOWLEDGMENTS}

The authors are grateful to the staff of Departamento de Acuicultura, Universidad Católica del Norte, for their collaboration. We also thanks to Elisabeth von Brand and Pilar Haye for kindly reviewing the manuscript.

\section{BIBLIOGRAPHY}

Bahamonde, N. \& I. Vila. 1971. Sinopsis sobre la biología del camarón de río del norte. Biología Pesquera, Chile. 5: 3-60.
BÁez, P., J. SAnzana \& J. Weinborn. 1983. Contribución al conocimiento de la morfología larvaria de Cryphiops caementarius, camarón de río del Norte de Chile. Bol. Mus. Nac. Hist. Nat. Chile. 40: 153-172.

Castro, C. 1966. El camarón de río del norte Cryphiops caementarius (Molina). Est. Oceanol. Chile. 2: 11-19.

EliAs, J. 1960. Contribución al comportamiento del camarón de río Cryphiops caementarius (Molina) Decapoda: Palemonidae. Pesca y Caza, Lima, Perú. 10: 84-106.

Hartmann, G. 1958. Apuntes Sobre la Biología del Camarón de Río, Cryphiops caementarius (Molina), Palaemonidae, Decapoda. Rev. Pesca y Caza. Min. Agric. Lima, Perú. 8:15-28.

HERnÁNDEZ, J. 1981. Estudio bioecológico del camarón Cryphiops caementarius de los ríos Huasco y Copiapó. Convenio SERPLAC III Región, Atacama y Fundación Chile. $N^{\circ}$ reg. 13699. 98 pp.

Jalihal, D.R., K.N Sankolli \& S. Shakuntala. 1993. Evolution of Larval Developmental of Freshwaterization in the Prawns Genus Macrobrachium Bate, 1868 (Decapoda, Palaemonidae). Crustaceana. 65(3): 365-376.

Munaylla, U. 1977. Desarrollo Larval del "Camarón de río" Cryphiops caementarius (Molina, 1832): Determinación y Descripción de sus Estadíos Larvarios. Rev. Documenta. 26: 13-16.

NAva, H. 1980. Técnicas de cultivo de larvas del camarón de río Cryphiops caementarius. M. Depto. Piscicultura y Oceanología, Universidad Nacional Agraria, Aptdo, Lima. 456 pp.

New, M. \& S.Singholka. 1984. Cultivo del Camarón de agua dulce, Manual para el cultivo de Macrobrachium rosenbergii. FAO Documento Técnico de Pesca 225 Roma.

New, M. 1995. Status of freshwater prawn farming: a review. Aquaculture Research. 26: 1-54.

NEw, M. 2005. Freshwater prawn farming: global, status, recent, research and a glance at the future. Aquaculture Research. 36: 210-230

Norambuena, R. 1977. Antecedentes biológicos de Cryphiops caementarius (Molina, 1782) en el estero "El Culebrón" (Crustacea, Decapoda, Palaemonidae). Biol. Pesq. Chile. 9: 7-19.

Rivera, M., P. Schmiede \& J. Meruane. 1983. Desarrollo larval del camarón de río del norte Cryphiops caementarius (Molina, 1782) (Crustacea: Palaemonidae), en condiciones de laboratorio. Symp. Intern. Acuacult., Coquimbo, Chile: 315334.

Rivera, M., \& J. Meruane. 1987. Effects of Salinity and Food on Larval Survival and Metamorphosis on Cryphiops caementarius (Molina, 1782) (Crustacea: Palaemonidae). Reports of the Usa Marine Biological Institute, Kochi University. 9: 207-214.

SANZANA, J. 1976. Estadios larvarios del "camarón de 
Gayana 70(2), 2006

río" Cryphiops caementarius (Molina) (Decapoda, Palaemonidae). Depto. Agricultura, Universidad del Norte, Arica. 4: 47-55.

Schmiede, P., M. Rivera \& J. Meruane. 1982. Morfología larval de Cryphiops caementarius (Molina) (Crustacea, Palaemonidae). Resúmenes Segun- das Jornadas Ciencias del Mar. U. de Concepción. p. 24.

Viacava, M., R. Aitaken \& J. Llanos. 1978. Estudio del Camarón en el Perú. Bol. Instituto del Mar del Perú. 3(5):161-232.

Fecha de recepción: 25.08.05

Fecha de aceptación: 08.05.06 